\title{
$\begin{array}{lllllllll}\mathrm{I} & \mathrm{N} & \mathrm{S} & \mathrm{T} & \mathrm{I} & \mathrm{T} & \mathrm{U} & \mathrm{T} & \mathrm{E}\end{array}$
}

\section{Many New Hampshire Jobs Do Not Pay a Livable Wage}

\author{
DAPHNE KENYON AND ALLISON CHURILLA
}

A $S$ THIS REPORT GOES TO PRESS, the stock market is in a slow-motion crash and the U.S. economy faces the worst financial crisis since the 1930s. ${ }^{1}$ The U.S. economy is faltering and the unemployment rate has jumped to the highest level in nearly five years. ${ }^{2}$ While forecasts indicate New Hampshire has not fallen into recession, other indicators suggest a considerable portion of families in the state are struggling. ${ }^{3}$ In the first six months of 2008, real estate foreclosures were up 62 percent from 2007 and up 152 percent from 2006. ${ }^{4}$ State revenues have fallen, placing New Hampshire among the states with the greatest tax shortfalls. ${ }^{5}$ Forty-one percent of voters say jobs and the economy are the most important issues affecting their vote for the November election, more important than Iraq, health care, terrorism, and gas prices. $^{6}$

Given this strained economic climate, it is important to take inventory of households' ability to locate gainful employment in the state. Analyses in this brief show a considerable proportion of New Hampshire jobs do not pay a livable wage, or a household wage sufficient to pay for basic needs such as housing, food, transportation, child care, and healthcare.

Estimates of the portion of jobs paying a livable wage range from 13 percent to 73 percent and vary by family type and region of the state. For example, over 60 percent of New Hampshire jobs pay a livable wage for single-person households or one-child families in which both parents work. In contrast, only 21 percent of New Hampshire jobs pay a livable wage for single-parent families with two young children. Across family types, Carroll County consistently has the lowest percentage of livable wage jobs, whereas Hillsborough and Sullivan are among the counties with the highest percentage of livable wage jobs.

This brief builds on findings presented in the New Hampshire Basic Needs and Livable Wage 2006 study, which provided statewide and sub-state estimates of liv- able wages for different family types. Here, those livable wage estimates are updated to 2007 and used to calculate the proportion of New Hampshire jobs that pay a livable wage across family types and regions of the state. The brief concludes with a forecast of state unemployment rates, which should be considered alongside estimates of the proportion of New Hampshire jobs paying a livable wage when assessing the job climate.

\section{Livable Wage Varies by Family Type and Region of the State}

A livable wage is a wage sufficient to pay for basic needs, which include food, rent, utilities, basic phone service, clothing and household expenses, transportation by automobile, child care, healthcare, and a small allowance for personal expenses. The 2006 report that preceded this brief, entitled New Hampshire Basic Needs and Livable Wage 2006, estimated the wage persons would have to earn in order to be self-sufficient and pay for the necessities of life.

Understanding that expenses differ by household type, the study calculated livable wage estimates for seven family types: a single person, a single parent with one child, a single parent with two children, two parents with one child (one parent working), two parents with one child (both parents working), two parents with two children (one parent working), and two parents with two children (both parents working). When both parents are working, the livable wage was the estimated hourly wage each adult would have to earn in order for the family to be self-sufficient. Children were assumed to be young ${ }^{7}$ and to require full-time care either by a non-working parent in the home or by an independent child care provider outside the home. 
Table 1: Estimated Livable Wage by County and Household Type, 2007

\begin{tabular}{|c|c|c|c|c|c|c|c|c|c|c|c|}
\hline Family Unit & Belknap & Carroll & Cheshire & Coos & Grafton & Hillsborough & Merrimack & Rockingham & Strafford & Sullivan & $\begin{array}{c}\text { NH } \\
\text { Average }\end{array}$ \\
\hline $\begin{array}{l}\text { Two parents and } \\
\text { two children } \\
\text { both parents } \\
\text { working }\end{array}$ & $\$ 11.65$ & $\$ 11.51$ & $\$ 11.93$ & $\$ 9.85$ & $\$ 11.32$ & $\$ 12.86$ & $\$ 12.47$ & $\$ 13.09$ & $\$ 12.15$ & $\$ 11.42$ & $\$ 12.42$ \\
\hline $\begin{array}{l}\text { Two parents and } \\
\text { two children } \\
\text { one parent } \\
\text { working }\end{array}$ & $\$ 17.97$ & $\$ 17.96$ & $\$ 18.92$ & $\$ 16.04$ & $\$ 17.73$ & $\$ 19.22$ & $\$ 19.09$ & $\$ 19.34$ & $\$ 18.72$ & $\$ 17.60$ & $\$ 18.83$ \\
\hline $\begin{array}{l}\text { Two parents and } \\
\text { one children } \\
\text { both parents } \\
\text { working }\end{array}$ & $\$ 10.03$ & $\$ 9.92$ & $\$ 10.32$ & $\$ 8.49$ & $\$ 9.82$ & $\$ 11.11$ & $\$ 10.87$ & $\$ 11.30$ & $\$ 10.55$ & $\$ 9.95$ & $\$ 10.73$ \\
\hline $\begin{array}{l}\text { Two parents and } \\
\text { one children } \\
\text { one parent } \\
\text { working }\end{array}$ & $\$ 15.99$ & $\$ 15.98$ & $\$ 16.94$ & $\$ 16.19$ & $\$ 15.75$ & $\$ 17.24$ & $\$ 17.11$ & $\$ 17.34$ & $\$ 16.75$ & $\$ 15.62$ & $\$ 16.85$ \\
\hline $\begin{array}{l}\text { Single person } \\
\text { and two children }\end{array}$ & $\$ 19.04$ & $\$ 18.72$ & $\$ 19.61$ & $\$ 15.40$ & $\$ 18.34$ & $\$ 21.73$ & $\$ 20.72$ & $\$ 22.24$ & $\$ 20.06$ & $\$ 18.54$ & $\$ 20.72$ \\
\hline $\begin{array}{l}\text { Single person and } \\
\text { one child }\end{array}$ & $\$ 16.48$ & $\$ 16.27$ & $\$ 17.09$ & $\$ 13.38$ & $\$ 16.08$ & $\$ 18.82$ & $\$ 18.16$ & $\$ 19.24$ & $\$ 17.53$ & $\$ 16.33$ & $\$ 18.01$ \\
\hline Single person & $\$ 10.22$ & $\$ 10.38$ & $\$ 10.73$ & $\$ 9.21$ & $\$ 10.14$ & $\$ 11.45$ & $\$ 11.30$ & $\$ 11.20$ & $\$ 11.55$ & $\$ 10.62$ & $\$ 11.07$ \\
\hline
\end{tabular}

Source: Calculations by authors based on data from Kenyon, Daphne A. 2006. “New Hampshire's Basic Needs and Livable Wage." UNH Office of Economic Initiatives and the North Country Council, Concord, NH.

Table 1 updates the livable wage estimates to 2007 using the Northeast Consumer Price Index. ${ }^{8}$ As the table indicates, the livable wage varies considerably by family type and county. For New Hampshire, the lowest estimated livable wage is $\$ 10.73$ for a two parent family with one child (both parents working), while the highest livable wage estimate is $\$ 20.72$ for a single person with two children. Dual-earner families and households without children are at an obvious advantage in locating livable wage jobs, as their household expenses are lower and/or shared with another adult.

Livable wage estimates are lowest for Coos County, where housing prices and other household expenses tend to be lower, and highest for Hillsborough and Rockingham Counties. These two counties are home to three of the largest cities in the state: Manchester and Nashua (both in Hillsborough County) and Portsmouth (in Rockingham County). Table 2 presents updated estimates of the livable wage in these and two other large cities: Concord (in
Merrimack County) and Rochester (in Strafford County). Because living expenses tend to be similar in cities, livable wage estimates do not vary nearly as much among New Hampshire cities as they do among counties in the state.

\section{Greater Availability of Livable Wage Jobs for Households Without Children and Dual Earner Families}

Like the livable wage estimates, the proportion of livable wage jobs available in the state depends enormously upon family type. In every county in the state, well over half of all jobs pay a livable wage for a two-parent family with one child (both parents working) or for a single person household. In contrast, no more than a quarter of all jobs in any county pay a livable wage for a single person with two young children. 
Table 2: Estimated Livable Wage by City and Household Type, 2007

\begin{tabular}{|c|c|c|c|c|c|}
\hline Family Unit & Concord & Manchester & Nashua & Portsmouth & Rochester \\
\hline $\begin{array}{l}\text { Two parents and one child } \\
\text { both parents working }\end{array}$ & $\$ 11.09$ & $\$ 11.02$ & $\$ 11.33$ & $\$ 11.42$ & $\$ 10.67$ \\
\hline $\begin{array}{l}\text { Two parents and one child } \\
\text { one parent working }\end{array}$ & $\$ 17.53$ & $\$ 17.24$ & $\$ 17.32$ & $\$ 17.51$ & $\$ 16.97$ \\
\hline Single person and two children & $\$ 21.21$ & $\$ 21.58$ & $\$ 22.34$ & $\$ 22.63$ & $\$ 20.47$ \\
\hline Single person and one child & $\$ 18.60$ & $\$ 18.66$ & $\$ 19.29$ & $\$ 19.46$ & $\$ 17.76$ \\
\hline
\end{tabular}

Source: Calculations by authors based on data from Kenyon, Daphne A. 2006. “New Hampshire's Basic Needs and Livable Wage." UNH Office of Economic Initiatives and the North Country Council, Concord, NH.

Table 3: Estimated Percentage of Jobs Paying a Livable Wage By County and Household Type, 2007

\begin{tabular}{l|c|c|c|c|c|c|c|c|c|c|c}
\hline \multicolumn{1}{c}{ Family Unit } & \multicolumn{1}{c}{ Belknap } & \multicolumn{1}{c}{ Carroll } & \multicolumn{1}{c}{ Cheshire } & Coos & Grafton & Hillsborough & Merrimack & Rockingham & Strafford & Sullivan & $\begin{array}{c}\text { NH } \\
\text { Average }\end{array}$ \\
\hline $\begin{array}{l}\text { Two parents and } \\
\text { two children } \\
\text { both parents } \\
\text { working }\end{array}$ & $48 \%$ & $47 \%$ & $48 \%$ & $50 \%$ & $58 \%$ & $56 \%$ & $53 \%$ & $49 \%$ & $53 \%$ & $60 \%$ & $53 \%$ \\
\hline $\begin{array}{l}\text { Two parents and } \\
\text { two children } \\
\text { oneparentworking }\end{array}$ & $17 \%$ & $16 \%$ & $18 \%$ & $21 \%$ & $26 \%$ & $31 \%$ & $25 \%$ & $23 \%$ & $23 \%$ & $27 \%$ & $25 \%$ \\
\hline $\begin{array}{l}\text { Two parents and } \\
\text { one children } \\
\text { both parents } \\
\text { working }\end{array}$ & $59 \%$ & $60 \%$ & $58 \%$ & $64 \%$ & $68 \%$ & $65 \%$ & $63 \%$ & $57 \%$ & $65 \%$ & $73 \%$ & $63 \%$ \\
\hline $\begin{array}{l}\text { Two parents and } \\
\text { one children } \\
\text { one parent working }\end{array}$ & $24 \%$ & $22 \%$ & $25 \%$ & $21 \%$ & $33 \%$ & $37 \%$ & $30 \%$ & $29 \%$ & $30 \%$ & $33 \%$ & $31 \%$ \\
\hline $\begin{array}{l}\text { Single person } \\
\text { and two children }\end{array}$ & $15 \%$ & $13 \%$ & $17 \%$ & $23 \%$ & $25 \%$ & $25 \%$ & $20 \%$ & $18 \%$ & $20 \%$ & $22 \%$ & $21 \%$ \\
\hline $\begin{array}{l}\text { Single person and } \\
\text { one child }\end{array}$ & $22 \%$ & $21 \%$ & $24 \%$ & $28 \%$ & $32 \%$ & $32 \%$ & $27 \%$ & $23 \%$ & $27 \%$ & $30 \%$ & $28 \%$ \\
\hline \begin{tabular}{l} 
Single person \\
\hline
\end{tabular} & $56 \%$ & $56 \%$ & $56 \%$ & $56 \%$ & $66 \%$ & $62 \%$ & $61 \%$ & $58 \%$ & $56 \%$ & $67 \%$ & $61 \%$ \\
\hline
\end{tabular}

Source: Calculations by aUthors based on data from New Hampshire Employment Security Economic and Labor Market Information Bureau, “2007 New Hampshire County OcCupational EMployment and Wages.” 
Table 4: Estimated Percentage of Jobs Paying a livable Wage, By City and Household Type, 2007

\begin{tabular}{l|c|c|c|c|c}
\hline \multicolumn{1}{c}{ Family Unit } & Concord & \multicolumn{1}{c}{ Manchester } & Nashua & Portsmouth & $\begin{array}{c}\text { Rochester } \\
\text { Average }\end{array}$ \\
\hline $\begin{array}{l}\text { Two parents and two children } \\
\text { both parents working }\end{array}$ & $51 \%$ & $55 \%$ & $54 \%$ & $51 \%$ & $51 \%$ \\
\hline $\begin{array}{l}\text { Two parents and two children } \\
\text { one parent working }\end{array}$ & $23 \%$ & $29 \%$ & $30 \%$ & $27 \%$ & $22 \%$ \\
\hline $\begin{array}{l}\text { Two parents and one child } \\
\text { both parents working }\end{array}$ & $61 \%$ & $65 \%$ & $63 \%$ & $63 \%$ & $60 \%$ \\
\hline $\begin{array}{l}\text { Two parents and one child } \\
\text { one parent working }\end{array}$ & $29 \%$ & $35 \%$ & $36 \%$ & $32 \%$ & $27 \%$ \\
\hline Single person and two children & $19 \%$ & $23 \%$ & $23 \%$ & $21 \%$ & $18 \%$ \\
\hline Single person and one child & $25 \%$ & $30 \%$ & $30 \%$ & $27 \%$ & $21 \%$ \\
\hline Single person & $59 \%$ & $65 \%$ & $60 \%$ & $61 \%$ & $26 \%$ \\
\hline
\end{tabular}

Source: Calculations by authors based on data from New Hampshire Employment Security Economic and Labor Market Information Bureau, “2007 New Hampshire County Occupational Employment and Wages.”

\section{Metropolitan Counties Offer Greater Opportunities to Find a Livable Wage}

The proportion of jobs paying a livable wage also varies by area of the state. The proportion of jobs paying a livable wage varies more by county than it does by city. Carroll County has the lowest percentage of livable wage jobs across all family types. Hillsborough County, which is home to two large cities in the state, has the highest percentages of livable wage jobs, followed by Sullivan and Grafton Counties.
Percentage of Livable Wage Jobs in New Hampshire is Similar to Other States

Studies in several other states have estimated the percentage of jobs paying a livable wage. ${ }^{9}$ Because these studies use somewhat different methodologies and data for different years, the estimates are not strictly comparable. However, one gets a sense that New Hampshire is fairly similar to some other states in the percentage of jobs paying a livable wage.

Table 5: Livable Wage Job Estimates from Other State Studies

\begin{tabular}{l|c|cc}
\hline \multicolumn{1}{c}{ State } & Year of Study & $\begin{array}{c}\text { Lower Estimate of Percentage of } \\
\text { Statewide Livable Wage Jobs }\end{array}$ & $\begin{array}{c}\text { Upper Estimate of Percentage of } \\
\text { Statewide Livable Wage Jobs }\end{array}$ \\
\hline Nevada & 2001 & $43 \%$ & $83 \%$ \\
\hline Washington & 2006 & $23 \%$ & $74 \%$ \\
\hline Oregon & 2006 & $20 \%$ & $69 \%$ \\
\hline Maine & 2004 & $66 \%$ & $66 \%$ \\
\hline Idaho & 2006 & $12 \%$ & $64 \%$ \\
\hline Vermont & 1997 & $22 \%$ & $64 \%$ \\
\hline New Hampshire & $\mathbf{2 0 0 7}$ & $\mathbf{2 1 \%}$ & $\mathbf{6 3 \%}$ \\
\hline Montana & 2006 & $15 \%$ & $60 \%$ \\
\hline
\end{tabular}

Source: See references Section for state Study Citations. Idaho, Montana, Oregon, and Washington estimates are all EMBEDDED IN THE NORTHWEST JOBS STUDIES. 
Table 6: Average Hourly Wages by County, 2007

\begin{tabular}{l|c}
\hline \multicolumn{1}{c}{ County } & $\begin{array}{c}\text { Average } \\
\text { Hourly Wage }\end{array}$ \\
\hline Belknap & $\$ 17.28$ \\
\hline Carroll & $\$ 15.75$ \\
\hline Cheshire & $\$ 17.31$ \\
\hline Coos & $\$ 15.29$ \\
\hline Grafton & $\$ 20.25$ \\
\hline Hillsborough & $\$ 21.39$ \\
\hline Merrimack & $\$ 19.06$ \\
\hline Rockingham & $\$ 19.54$ \\
\hline Strafford & $\$ 18.78$ \\
\hline Sullivan & $\$ 17.61$ \\
\hline New Hampshire Total & $\$ 19.60$ \\
\hline
\end{tabular}

Source: New Hampshire Employment Security Economic AND LABor Market INFORMation BureaU, “2007 NeW Hampshire County Occupational EMPloyment and WAGES."

Coinciding with these county-to-county differences in livable wage jobs, average hourly wages are lowest in Coos and Carroll Counties and highest in Hillsborough County. The range in average hourly wages is large, with the average wage in Coos County falling more than six dollars short of the $\$ 21.39$ average wage in Hillsborough County.

Similarly, unemployment rates are highest in Coos County. In 2007, the statewide unemployment rate was 3.6 percent, but unemployment rates ranged from three percent in Grafton and Sullivan Counties to 4.6 percent in Coos County.
Table 7: County Unemployment Rates, 2007

\begin{tabular}{l|c}
\hline \multicolumn{1}{c}{ County } & $\begin{array}{c}\text { Unemployment Rate } \\
\text { (2007 Annual Average) }\end{array}$ \\
\hline Belknap & $3.6 \%$ \\
\hline Carroll & $3.5 \%$ \\
\hline Cheshire & $3.6 \%$ \\
\hline Coos & $4.6 \%$ \\
\hline Grafton & $3.0 \%$ \\
\hline Hillsborough & $3.6 \%$ \\
\hline Merrimack & $3.3 \%$ \\
\hline Rockingham & $3.9 \%$ \\
\hline Strafford & $3.3 \%$ \\
\hline Sullivan & $3.0 \%$ \\
\hline New Hampshire Total & $\mathbf{3 . 6 \%}$ \\
\hline
\end{tabular}

Source: New Hampshire Employment Security Economic AND LABOR MARKeT INFORMATION BUREAU, “2007 LOCAL Area Unemployment Statistics.” Retrieved June 6, 2008.

\section{Workers in Service Occupations Have Difficulty Earning a Livable Wage}

Table 8 lists 65 jobs in the state with a median hourly wage below $\$ 11.07$ per hour, the estimated livable wage for a single person household in New Hampshire. One in three workers in the state is employed in one of these jobs, most of which are in service industries. The list includes cashiers (\$8.89), child care workers (\$9.03), fast food cooks (\$8.81), dishwashers (\$8.91), home health aides (\$10.97), maids (\$10.02), and retail salespersons (\$10.23). These occupations tend to offer low wages, sporadic hours, and few benefits.

Conversely, Tables 9 and 10 show the 40 occupations projected to grow the fastest from 2006 to 2016. Only two fast-growing occupations pay a median hourly wage that falls below the 2007 livable wage: home health aides and personal care aides. The remainder of the 40 fastest growing jobs pays a median hourly wage above the livable wage. The highest paying jobs on this list are in health care and computer technology, and include computer software engineer, veterinarian, physician assistants, and database administrators. 
Table 8: Jobs with Median Wage Below Livable Wage, 2007

\begin{tabular}{|c|c|c|c|}
\hline Occupation & $\begin{array}{c}\text { Estimated } \\
\text { Employment }\end{array}$ & $\begin{array}{c}\text { Percentage } \\
\text { of Total } \\
\text { State Jobs }\end{array}$ & $\begin{array}{l}2007 \text { Median } \\
\text { Hourly Wage }\end{array}$ \\
\hline Food Preparation and Serving-Related Occupations & 53,700 & $8.5 \%$ & $\$ 9.04$ \\
\hline Retail Salespersons & 24,050 & $3.8 \%$ & $\$ 10.23$ \\
\hline Cashiers & 22,470 & $3.6 \%$ & $\$ 8.89$ \\
\hline Personal Care and Service Occupations & 14,500 & $2.3 \%$ & $\$ 10.16$ \\
\hline Waiters and Waitresses & 12,030 & $1.9 \%$ & $\$ 7.42$ \\
\hline Combined Food Preparation and Serving Workers, Including Fast Food & 10,760 & $1.7 \%$ & $\$ 8.46$ \\
\hline Stock Clerks and Order Fillers & 10,070 & $1.6 \%$ & $\$ 10.93$ \\
\hline Maids and Housekeeping Cleaners & 3,890 & $0.6 \%$ & $\$ 10.02$ \\
\hline Office and Administrative Support Workers, All Other & 3,600 & $0.6 \%$ & $\$ 10.56$ \\
\hline Bartenders & 3,350 & $0.5 \%$ & $\$ 8.26$ \\
\hline Food Preparation Workers & 3,050 & $0.5 \%$ & $\$ 9.15$ \\
\hline Dishwashers & 3,040 & $0.5 \%$ & $\$ 8.91$ \\
\hline Packers and Packagers, Hand & 2,860 & $0.5 \%$ & $\$ 8.90$ \\
\hline Home Health Aides & 2,780 & $0.4 \%$ & $\$ 10.97$ \\
\hline Counter Attendants, Cafeteria, Food Concession, and Coffee Shop & 2,730 & $0.4 \%$ & $\$ 8.34$ \\
\hline Personal and Home Care Aides & 2,470 & $0.4 \%$ & $\$ 10.36$ \\
\hline Driver/Sales Workers & 2,430 & $0.4 \%$ & $\$ 8.79$ \\
\hline Counter and Rental Clerks & 2,410 & $0.4 \%$ & $\$ 10.70$ \\
\hline Child Care Workers & 2,290 & $0.4 \%$ & $\$ 9.03$ \\
\hline Hairdressers, Hairstylists, and Cosmetologists & 2,260 & $0.4 \%$ & $\$ 9.91$ \\
\hline Cooks, Fast Food & 2,060 & $0.3 \%$ & $\$ 8.81$ \\
\hline Hosts and Hostesses, Restaurant, Lounge, and Coffee Shop & 1,840 & $0.3 \%$ & $\$ 9.19$ \\
\hline Cooks, Short Order & 1,630 & $0.3 \%$ & $\$ 9.54$ \\
\hline Dining Room and Cafeteria Attendants and Bartender Helpers & 1,410 & $0.2 \%$ & $\$ 7.45$ \\
\hline Helpers-Production Workers & 1,350 & $0.2 \%$ & $\$ 10.95$ \\
\hline Recreation Workers & 1,300 & $0.2 \%$ & $\$ 10.83$ \\
\hline Hotel, Motel, and Resort Desk Clerks & 1,130 & $0.2 \%$ & $\$ 10.23$ \\
\hline Amusement and Recreation Attendants & 1,060 & $0.2 \%$ & $\$ 8.53$ \\
\hline Food Servers, Nonrestaurant & 1,040 & $0.2 \%$ & $\$ 9.07$ \\
\hline Cleaners of Vehicles and Equipment & 1,030 & $0.2 \%$ & $\$ 10.90$ \\
\hline Taxi Drivers and Chauffeurs & 1,000 & $0.2 \%$ & $\$ 10.70$ \\
\hline Laundry and Dry-Cleaning Workers & 940 & $0.1 \%$ & $\$ 9.76$ \\
\hline Library Assistants, Clerical & 840 & $0.1 \%$ & $\$ 10.78$ \\
\hline File Clerks & 760 & $0.1 \%$ & $\$ 10.65$ \\
\hline Nonfarm Animal Caretakers & 660 & $0.1 \%$ & $\$ 8.98$ \\
\hline Material Moving Workers, All Other & 540 & $0.1 \%$ & $\$ 9.47$ \\
\hline Service Station Attendants & 490 & $0.1 \%$ & $\$ 9.37$ \\
\hline Crossing Guards & 430 & $0.1 \%$ & $\$ 10.66$ \\
\hline Tire Repairers and Changers & 350 & $0.1 \%$ & $\$ 11.06$ \\
\hline
\end{tabular}




\begin{tabular}{|c|c|c|c|}
\hline Lifeguards, Ski Patrol, and Other Recreational Protective Service Workers & 330 & $0.1 \%$ & $\$ 10.36$ \\
\hline Personal Care and Service Workers, All Other & 290 & $0.0 \%$ & $\$ 9.24$ \\
\hline Photographic Processing Machine Operators & 290 & $0.0 \%$ & $\$ 10.11$ \\
\hline Veterinary Assistants and Laboratory Animal Caretakers & 290 & $0.0 \%$ & $\$ 9.65$ \\
\hline Ushers, Lobby Attendants, and Ticket Takers & 280 & $0.0 \%$ & $\$ 7.84$ \\
\hline Building Cleaning Workers, All Other & 270 & $0.0 \%$ & $\$ 8.45$ \\
\hline Cooks, All Other & 260 & $0.0 \%$ & $\$ 9.27$ \\
\hline Farmworkers and Laborers, Crop, Nursery, and Greenhouse & 240 & $0.0 \%$ & $\$ 9.06$ \\
\hline Food Preparation and Serving Related Workers, All Other & 220 & $0.0 \%$ & $\$ 8.65$ \\
\hline Ophthalmic Laboratory Technicians & 220 & $0.0 \%$ & $\$ 9.30$ \\
\hline Demonstrators and Product Promoters & 210 & $0.0 \%$ & $\$ 11.04$ \\
\hline Motor Vehicle Operators, All Other & 210 & $0.0 \%$ & $\$ 9.49$ \\
\hline Pressers, Textile, Garment, and Related Materials & 210 & $0.0 \%$ & $\$ 10.58$ \\
\hline Transportation Workers, All Other & 190 & $0.0 \%$ & $\$ 7.18$ \\
\hline Parking Lot Attendants & 180 & $0.0 \%$ & $\$ 10.06$ \\
\hline Woodworkers, All Other & 180 & $0.0 \%$ & $\$ 10.20$ \\
\hline Cementing and Gluing Machine Operators and Tenders & 150 & $0.0 \%$ & $\$ 10.73$ \\
\hline Bicycle Repairers & 110 & $0.0 \%$ & $\$ 10.82$ \\
\hline Pharmacy Aides & 100 & $0.0 \%$ & $\$ 10.83$ \\
\hline Media and Communication Equipment Workers, All Other & 90 & $0.0 \%$ & $\$ 9.32$ \\
\hline Tour Guides and Escorts & 90 & $0.0 \%$ & $\$ 9.11$ \\
\hline Baggage Porters and Bellhops & 80 & $0.0 \%$ & $\$ 10.29$ \\
\hline Motion Picture Projectionists & 60 & $0.0 \%$ & $\$ 8.51$ \\
\hline Cutters and Trimmers, Hand & 50 & $0.0 \%$ & $\$ 10.04$ \\
\hline Shoe and Leather Workers and Repairers & 30 & $0.0 \%$ & $\$ 10.08$ \\
\hline Watch Repairers & 30 & $0.0 \%$ & $\$ 10.65$ \\
\hline Total & 209,260 & $33.1 \%$ & \\
\hline
\end{tabular}

Source: New Hampshire Employment Security Economic and Labor Market Information Bureau, “2007 New Hampshire OCcupational Employment ANd Wages - Statewide.”

Table 9: Subset of Forty Fastest Growing Occupations with Median Wage BELOW Livable Wage, 2006-2016

\begin{tabular}{|c|c|c|c|}
\hline Occupation & $\begin{array}{l}\text { Estimated } \\
\text { Employment }\end{array}$ & $\begin{array}{c}\text { Percentage } \\
\text { of Total } \\
\text { State Jobs }\end{array}$ & $\begin{array}{l}2007 \text { Median } \\
\text { Hourly Wage }\end{array}$ \\
\hline Home Health Aides & 2,780 & $59.0 \%$ & $\$ 10.97$ \\
\hline Personal and Home Care Aides & 2,470 & $58.2 \%$ & $\$ 10.36$ \\
\hline
\end{tabular}

Source: New Hampshire Employment Security Economic and Labor Market Information Bureau,

"New Hampshire Employment Projections by Industry ANd Occupation, 2006-2016." 
Table 10: Subset of Forty Fastest Growing Occupations with Median Wage ABOVE Livable Wage, $2006-2016$

\begin{tabular}{|c|c|c|c|}
\hline Occupation & $\begin{array}{c}2007 \\
\text { Estimated } \\
\text { Employment }\end{array}$ & $\begin{array}{c}\text { Projected } \\
\text { Percent Change } \\
\text { 2006-2016 }\end{array}$ & $\begin{array}{l}2007 \text { Median } \\
\text { Hourly Wage }\end{array}$ \\
\hline Network Systems and Data Communications Analysts & 890 & $53.3 \%$ & $\$ 29.27$ \\
\hline Marriage and Family Therapists & 80 & $49.3 \%$ & $\$ 18.43$ \\
\hline Social and Human Service Assistants & 1,710 & $48.9 \%$ & $\$ 11.67$ \\
\hline Computer Software Engineers, Applications & 4,260 & $47.9 \%$ & $\$ 39.47$ \\
\hline Substance Abuse and Behavioral Disorder Counselors & 260 & $46.8 \%$ & $\$ 16.20$ \\
\hline Skin Care Specialists & 170 & $46.5 \%$ & $\$ 12.28$ \\
\hline Veterinary Technologists and Technicians & 660 & $45.1 \%$ & $\$ 14.39$ \\
\hline Personal Financial Advisors & 570 & $42.5 \%$ & $\$ 28.09$ \\
\hline Medical Assistants & 1,140 & $41.8 \%$ & $\$ 14.37$ \\
\hline Veterinarians & 300 & $39.7 \%$ & $\$ 36.90$ \\
\hline Physical Therapist Assistants & 310 & $39.6 \%$ & $\$ 20.38$ \\
\hline Pharmacy Technicians & 1,180 & $38.7 \%$ & $\$ 11.88$ \\
\hline Physician Assistants & 450 & $38.2 \%$ & $\$ 38.90$ \\
\hline Community and Social Service Specialists, All Other & 710 & $36.6 \%$ & $\$ 14.52$ \\
\hline Self-Enrichment Education Teachers & 1,090 & $36.0 \%$ & $\$ 24.68$ \\
\hline Dental Hygienists & 1,170 & $35.2 \%$ & $\$ 34.92$ \\
\hline Mental Health and Substance Abuse Social Workers & 410 & $35.0 \%$ & $\$ 16.29$ \\
\hline Dental Assistants & 1,200 & $34.7 \%$ & $\$ 18.77$ \\
\hline Medical and Public Health Social Workers & 380 & $34.1 \%$ & $\$ 22.58$ \\
\hline Financial Analysts & 800 & $34.1 \%$ & $\$ 31.83$ \\
\hline Physical Therapists & 1,060 & $34.0 \%$ & $\$ 31.03$ \\
\hline Mental Health Counselors & 390 & $33.9 \%$ & $\$ 18.43$ \\
\hline Sales Representatives, Services, All Other & 2,000 & $32.0 \%$ & $\$ 22.37$ \\
\hline Cardiovascular Technologists and Technicians & 250 & $31.7 \%$ & $\$ 23.81$ \\
\hline Rehabilitation Counselors & 720 & $31.4 \%$ & $\$ 13.99$ \\
\hline Counselors, All Other & 330 & $31.3 \%$ & $\$ 13.64$ \\
\hline Registered Nurses & 12,730 & $31.2 \%$ & $\$ 27.73$ \\
\hline Forensic Science Technicians & 40 & $31.1 \%$ & $\$ 24.55$ \\
\hline Database Administrators & 410 & $30.7 \%$ & $\$ 33.21$ \\
\hline Preschool Teachers, Except Special Education & 3,090 & $30.4 \%$ & $\$ 12.10$ \\
\hline Private Detectives and Investigators & 400 & $30.4 \%$ & $\$ 12.13$ \\
\hline Social and Community Service Managers & 130 & $30.3 \%$ & $\$ 23.40$ \\
\hline Child, Family, and School Social Workers & 690 & $30.2 \%$ & $\$ 19.65$ \\
\hline Computer Systems Analysts & 2,260 & $29.9 \%$ & $\$ 34.30$ \\
\hline Interpreters and Translators & 110 & $29.5 \%$ & $\$ 20.86$ \\
\hline Radiation Therapists & 60 & $28.9 \%$ & $\$ 37.90$ \\
\hline Occupational Therapists & 770 & $28.7 \%$ & $\$ 26.69$ \\
\hline Health Educators & 160 & $28.4 \%$ & $\$ 20.50$ \\
\hline
\end{tabular}


Table 11: Occupations Adding the Greatest Number of Jobs, 2006-2016

\begin{tabular}{|c|c|c|c|c|}
\hline Occupation & $\begin{array}{c}2007 \\
\text { Estimated } \\
\text { Employment }\end{array}$ & $\begin{array}{c}2016 \\
\text { Estimated } \\
\text { Employment }\end{array}$ & $\begin{array}{c}\text { Projected } \\
\text { New Jobs } \\
2006-2016\end{array}$ & $\begin{array}{c}2007 \\
\text { Median } \\
\text { Hourly Wage }\end{array}$ \\
\hline Retail Salespersons & 25,263 & 29,156 & 3,893 & $\$ 10.38$ \\
\hline Combined Food Preparation and Serving Workers, Including Fast Food & 10,740 & 13,281 & 2,541 & $\$ 8.37$ \\
\hline Computer Software Engineers, Applications & 4,534 & 6,705 & 2,171 & $\$ 39.47$ \\
\hline Office Clerks, General & 13,982 & 16,140 & 2,158 & $\$ 13.45$ \\
\hline Elementary School Teachers, Except Special Education & 8,077 & 10,117 & 2,040 & $\$ 30.92$ \\
\hline Waiters and Waitresses & 12,170 & 14,169 & 1,999 & $\$ 7.10$ \\
\hline Personal and Home Care Aides & 2,691 & 4,256 & 1,565 & $\$ 9.99$ \\
\hline Bookkeeping, Accounting, and Auditing Clerks & 10,364 & 11,915 & 1,551 & $\$ 15.76$ \\
\hline Landscaping and Groundskeeping Workers & 6,292 & 7,645 & 1,353 & $\$ 11.82$ \\
\hline Home Health Aides & 2,247 & 3,573 & 1,326 & $\$ 10.97$ \\
\hline Receptionists and Information Clerks & 5,708 & 6,851 & 1,143 & $\$ 12.22$ \\
\hline Child Care Workers & 4,119 & 5,192 & 1,073 & $\$ 9.09$ \\
\hline
\end{tabular}

Source: New Hampshire Employment Security Economic and Labor Market Information Bureau, "New Hampshire EMPloyment Projections by IndUSTRY AND OCCUPATION, 2006-2016."

A less optimistic picture results from examining the occupations adding the greatest number of jobs from 2006 to 2016. Table 11 shows that many of these jobs pay modest hourly wages and several of these jobs pay less than a livable wage. These include fast food workers, waiters and waitresses, personal and home care aides, and child care workers.

\section{Workers Earning Less than the Livable Wage Make Compromises}

How do workers manage without a livable wage? Some households may not be able to meet expenses for certain necessities, forcing them to do without these basic needs. Health insurance is the primary example; low-wage workers often decide not to purchase health insurance, whether employer-sponsored insurance is available or not.

Individuals may work more than 40 hours per week. Certain jobs, such as waiter or waitress, earn additional income from tips. In some cases other family resources en- able a worker to afford basic needs without earning a livable wage. For example, it is increasingly common for young people to live with their parents well into their twenties. In other families, one spouse may earn considerably more than the other, enabling the lower-earning spouse to earn less than the livable wage without imposing a financial hardship on the family. Finally, some families rely on relatives to provide for some of their basic needs, such as when grandparents provide free child care for their grandchildren.

Lastly, the safety net of federal, state and local government may help fill the gap between the cost of a household's basic needs and the income derived from a job paying less than the livable wage. Income support through the Earned Income Tax Credit, food stamps, or subsidized health care may help some households afford the necessities of life. At the same time, income limits for most government programs limit eligibility to very poor households. 


\section{Conclusion}

Two forces are likely to have the greatest impact on the projected availability of livable wage jobs in coming years. The first is the course of the current economic downturn. Table 11 shows the New England Economic Partnership (NEEP) forecast for New Hampshire's unemployment rate from 2008 to 2012. As the table shows, unemployment is projected to increase from 3.7 percent in 2007 to 4.2 percent in 2009, after which it is projected to gradually fall. The latest NEEP forecast predicted a relatively mild economic contraction, which provides some reason for optimism among New Hampshire workers. However, any optimism should be

Table 12: New Hampshire Unemployment Rate, HISTORY AND FORECAST

\begin{tabular}{|c|c|}
\hline Year & $\begin{array}{c}\text { Unemployment Rate } \\
\text { (Annual Average) }\end{array}$ \\
\hline 1987 & $2.5 \%$ \\
\hline 1988 & $2.5 \%$ \\
\hline 1989 & $3.4 \%$ \\
\hline 1990 & $5.6 \%$ \\
\hline 1991 & $7.2 \%$ \\
\hline 1992 & $7.5 \%$ \\
\hline 1993 & $6.6 \%$ \\
\hline 1994 & $4.6 \%$ \\
\hline 1995 & $4.0 \%$ \\
\hline 1996 & $4.2 \%$ \\
\hline 1997 & $3.1 \%$ \\
\hline 1998 & $2.9 \%$ \\
\hline 1999 & $2.7 \%$ \\
\hline 2000 & $2.7 \%$ \\
\hline 2001 & $3.4 \%$ \\
\hline 2002 & $4.6 \%$ \\
\hline 2003 & $4.5 \%$ \\
\hline 2004 & $3.9 \%$ \\
\hline 2005 & $3.6 \%$ \\
\hline 2006 & $3.5 \%$ \\
\hline 2007 & $3.6 \%$ \\
\hline $2008 f$ & $3.8 \%$ \\
\hline $2009 f$ & $4.2 \%$ \\
\hline $2010 \mathrm{f}$ & $4.0 \%$ \\
\hline $2011 \mathrm{f}$ & $3.7 \%$ \\
\hline $2012 f$ & $3.6 \%$ \\
\hline
\end{tabular}

SOURCE: U.S. STATISTICAL ABSTRACT, VARIOUS YeARS, AND New England Economic Partnership, conference FORECASTS, MAY 2008 AND VARIOUS YEARS. tempered by the fact that the latest forecast was issued before the dramatic stock market decline and at the beginning of the financial crisis.

The second major factor impacting the availability of livable wage jobs is the changing composition of New Hampshire's economic base. Between 2000 and 2007, New Hampshire lost 25,400 manufacturing jobs, representing a 25 percent decline in the industry. ${ }^{10}$ Over the same period, jobs in education, healthcare, retail trade, and leisure and hospitality grew by about the same number of jobs. To the extent New Hampshire continues in this transition from a production-based to a service-based economy, the proportion of livable wage jobs is expected to decline.

\section{Methodology}

Livable wage estimates in this report rely on 2005 estimates contained in the report New Hampshire's Basic Needs and Livable Wage 2006. Estimates were adjusted for inflation to 2007 dollars using the Northeast Consumer Price Index, which increases livable wage estimates by 6.3 percent between 2005 and 2007.

Estimates of the percentage of livable wage jobs are based on livable wage estimates noted above and occupational wage data from the New Hampshire Department of Employment Security (NHES) Economic and Labor Market Information Bureau (ELMIB). Wage data for the state and areas within the state are part of the national Occupational Employment Statistics program, a semiannual survey of employers and employing units conducted by the Bureau of Labor Statistics (BLS) in cooperation with state employment security agencies. Over 1,800 employers in New Hampshire were surveyed between March 2006 and January 2007 to produce the employment and wage data used in this report. ${ }^{11}$ Several groups of workers are not included in this survey: the self-employed, owners/partners in unincorporated firms, household workers, and unpaid family workers. In addition, since the survey covers New Hampshire employers, it excludes data on New Hampshire workers employed outside of New Hampshire and includes data on out-of-state workers employed in New Hampshire.

The wage data classifies workers into over 600 detailed occupations including, for example, retail salespersons, cashiers, registered nurses, and waiters and waitresses. For each detailed occupation, NHES ELMIB provides an estimated employment count and mean, median, 25th percentile, and 75th percentile wages for workers in the occupation. In this report, livable wage job estimates assume a uniform distribution of wages to extrapolate a minimum and maximum wage in each occupation.

The livable wage estimate was compared to wages at the minimum, 25th percentile, median, 75th percentile, and maximum to estimate the number of livable wage jobs in 
each occupation. If the minimum wage was more than the livable wage estimate, all jobs in the occupation were classified as paying a livable wage; conversely, if the maximum wage was less than the livable wage estimate, all jobs in the occupation were classified as not paying a livable wage. For other relationships between the estimated livable wage and wages for a particular job category, Excel formulas were used to produce sensible estimates. For example, if the livable wage was equal to the 25 th percentile wage in a particular occupation, 75 percent of the jobs were classified as paying a livable wage; if the livable wage was equal to the 75th percentile wage in a particular occupation, 25 percent of the jobs were classified as paying a livable wage.

Jobs paying a livable wage in each occupation were

\section{Endnotes}

1 E.S. Browning and Annelena Lobb, "Market's 7-Day Rout Leaves U.S. Reeling," Wall Street Journal, October 10, 2008; Jon Hilsenrath, Serena Ngand and Damian Paletta, "Worst Crisis Since '30s, With No End Yet in Sight," Wall Street Journal, September 18, 2008.

${ }^{2}$ Kelly Evans, Bob Davis, and Tom Lauricella. "Jobless Rate Tops 6\%, Fueling Fight on Economy." Wall Street Journal, September 6-7, 2008.

3 “U.S. Regional Recession Status." Dismal Scientist, MoodysEconomy.com., Accessed October 10, 2008 at www. economy.com/dismal/recession.asp; New England Economic Partnership, Economic Outlook: 2008-2012, Walpole, MA.

4 “Total Foreclosures in New Hampshire by County," www. foreclosuresnh.com/files/New_Hampshire_stats.xls.

${ }^{5}$ Connor Dougherty, Amy Merrick, and Anton Troianovski, "States Slammed by Tax Shortfalls," Wall Street Journal, July 24, 2008.

${ }^{6}$ Andrew E. Smith, Ph.D., Granite State Poll, The University of New Hampshire, July 21, 2008.

7 A single child was assumed to be four years old; two children were assumed to be four and six years of age.

${ }^{8}$ According to the Economic Policy Institute methodology guide, updating livable wage estimates using the CPI can produce reasonable new estimates as long as the time between the original estimates and the date in question is no more than five years. For periods over five years, using this updating method becomes problematic, in part because the costs of different components of a household's budget can change in very different ways. summed for the entire state to produce an estimate of the proportion of livable wage jobs in New Hampshire. Livable wage job estimates were also calculated for the ten counties and five cities within the state.

NHES ELMIB makes wage data available for the state and certain sub-state divisions, such as counties. To protect the confidentiality of workers and employers, employment counts and wage estimates are not made available for specific occupations when employment counts are low. As a result, wage data are available for 99 percent of the estimated 632,590 jobs occupied in New Hampshire. For the 10 counties, the availability of wage data ranges from 66 percent of jobs in Coos County to 96 percent of jobs in Hillsborough County.

9 Chandler, Susan and Alicia Smalley. 2001. "Working Hard, Living Poor: Nevada Basic Needs and a Living Wage." Progressive Leadership Alliance of Nevada, Reno, NV. Last accessed August 15, 2008 (http://planevada.org/images/ PDFs/working01.pdf); Chinitz, Julie, Dennis Osorio, Jill Reese, and Gerald Smith. 2007. "The Race for Wages: Living Wage Jobs in the Current Economy." Northwest Federation of Community Organizations, Seattle, WA. Last accessed August 15, 2008 (http://www.nwfco.org/pubs/2007.1218_ NW.JG.The.Race.For.Wages.pdf); Fu, ChienHao, Dennis Osorio, Jill Reese, and Gerald Smith. 2007. "Living in the Red: Northwest Family Budgets Falling Behind." Northwest Federation of Community Organizations, Seattle, WA. Last accessed August 15, 2008 (http://www.nwfco.org/ pubs/2007.1009_NW.Job.Gap.Living.in.the.red.pdf); Kahler, Ellen and Doug Hoffer. 1997. "The Vermont Job Gap Study - Livable Wage Jobs: The Job Gap.” Vermont Peace \& Justice Center, Burlington, VT. Last accessed August 27, 2008 (http://www.vtlivablewage.org/JOBGAP2a.pdf); Maine Development Foundation. 2004. "Measures of Growth 2004: Performance Measures and Benchmarks to Achieve a Vibrant and Sustainable Economy for Maine." Maine Economic Growth Council, Augusta, ME. Last accessed August 15, 2008 (http://www.mdf.org/megc/measures/megc2004. pdf).

${ }^{10}$ Churilla, Allison. 2007. The State of Working New Hampshire 2007. University of New Hampshire Carsey Institute, Durham, NH.

${ }^{11}$ For more information on the administration of the Occupation Employment Statistics program in New Hampshire, see http://www.nh.gov/nhes/elmi/pdfzip/econstat/salsurvey/2007/Wages2007intro.pdf. 


\section{A U T H O R S}

Daphne A. Kenyon, Ph.D. is an economist who serves as a Policy Fellow at the Carsey Institute and as Visiting Fellow at the Lincoln Institute of Land Policy. She is the author of New Hampshire's Basic Needs \& Livable Wage 2006.

Allison Churilla is a policy fellow at the Carsey Institute and a Ph.D. candidate in the Department of Sociology at the University of New Hampshire (allison.churilla@unh.edu).

\section{A C K N O W L E D G E M E N T S}

Many thanks to Bethany Paquin for her research assistance and editing and to Chris Jeffords for checking the nested if-statements in the Excel calculations. Thanks to Marty Capodice, former research analyst with New Hampshire Employment Security and consultant and Ross Gittell, James R. Carter Professor \& Professor of Management, Whittemore School of Business and Economics, University of New Hampshire for their helpful comments on a previous draft.

\section{CARSEY}

Building knowledge for families and communities

The Carsey Institute is a leading center for policy research on vulnerable children, youth, and families and sustainable community development. We give policy makers and practitioners timely, independent resources to effect change in their communities.

Huddleston Hall

73 Main Street

Durham, NH 03824

(603) 862-2821

www.carseyinstitute.unh.edu

This brief was created with support from the New Hampshire Charitable Foundation.

\section{$\triangle$ UNIVERSITY of NEW HAMPSHIRE}

